\title{
RESULTS OF SURGICAL TREATMENT IN THE CRANIOCERVICAL JUNCTION IN MUCOPOLYSACCHARIDOSIS
}

\author{
RESULTADOS DO TRATAMENTO CIRÚRGICO NA JUNÇÃO CRANIOCERVICAL NAS \\ MUCOPOLISSACARIDOSES
}

\author{
RESULTADOS DEL TRATAMIENTO QUIRÚRGICO EN LA UNIÓN \\ CRANEOCERVICAL EN LAS MUCOPOLISACARIDOSIS
}

\author{
Luís Eduardo Carelli Teixeira da Silva1, Alderico Girão Campos de Barros ${ }^{1}$, Lucas Rocha Cavalcanti' ${ }^{1}$, Caloue Jauhar de Castro', \\ Renato Henriques Tavares ${ }^{1}$, Raphael Teofilo de Souza' ${ }^{1}$
}

1. Instituto Nacional de Traumatologia e Ortopedia - Rio de Janeiro, RJ, Brasil

\begin{abstract}
Objective: Evaluate the results after decompression and stabilization of craniocervical junction in patients with mucopolysaccharidosis (MPS). Method: Retrospective study of 10 patients with MPS through the analysis of medical records and additional tests. Result: All patients with mid-term and long-term follow-up achieved consolidation of the arthrodesis and $87.5 \%$ had neurological improvement of Nurick score. Conclusion: Early diagnosis and intervention in cases of stenosis and/or craniocervical instability of patients with MPS provide patients a good recovery of neurological function, despite the great technical difficulty and risk of complications.
\end{abstract}

Keywords: Mucopolysaccharidosis IV; Spinal cord compression; Spinal Cord Diseases.

\section{RESUMO}

Objetivo: Avaliar os resultados após a descompressão e estabilização da junção craniocervical em pacientes portadores de mucopolissacaridose (MPS). Método: Estudo retrospectivo de 10 pacientes portadores de MPS, por meio da análise de prontuário e de exames complementares. Resultado: Todos os pacientes com acompanhamento a médio e longo prazo atingiram a consolidação da artrodese e 87,5\% tiveram melhora neurológica no escore Nurick. Conclusão: O diagnóstico e a intervenção precoces em casos de estenose e/ou instabilidade craniocervical em pacientes com MPS proporcionam aos pacientes uma boa recuperação da função neurológica, apesar da grande dificuldade técnica e do risco de complicações.

Descritores: Mucopolissacaridose IV; Compressão de medula espinhal; Doenças da medula espinhal.

\section{RESUMEN}

Objetivo: Evaluar los resultados después de la descompresión y estabilización de la unión craneocervical en pacientes con mucopolisacaridosis (MPS). Método: Estudio retrospectivo con 10 pacientes con mucopolisacaridosis, a través del análisis de las historias clínicas y de pruebas complementarias. Resultado: Todos los pacientes con seguimiento a medio y largo plazo alcanzaron la consolidación de la artrodesis y 87,5\% presentaron mejoría neurológica de la puntuación Nurick. Conclusión: El diagnóstico e intervención temprana en casos de estenosis y/o inestabilidad craneocervical en pacientes con MPS proporcionan a los pacientes una buena recuperación de la función neurológica, a pesar de la gran dificultad técnica y el riesgo de complicaciones.

Descriptores: Mucopolisacaridosis IV; Compresión de la médula espinal; Enfermedades de la médula espinal.

\section{INTRODUCTION}

Mucopolysaccharidoses (MPS) comprise a group of genetic diseases with monogenic, autosomal, recessive defect. It is a disease caused by an enzyme deficiency in the lysosomal metabolism of glucosaminoglycans (GAGs), resulting, in the final analysis, in a build-up of these substances in various tissues. ${ }^{1}$ Given that GAGs are primarily found in areas with stroma, the connective tissue, skeletal system and cardiac valves become the main sites of disease in MPS. There are eleven subtypes, classified according to the enzyme that is deficient. $^{2}$ The initial symptoms are only observed after the first years of life, with growth deficit and skeletomuscular changes, therefore recognition of the diagnosis by the orthopedic doctor is fundamental. Hip dysplasia, genu valgus and carpal tunnel syndrome are among these changes. Others, related specifically to the vertebral spine, include cervical stenosis, occipitocervical instability, thoracolumbar kyphosis and scoliosis. With the advent of enzyme replacement therapy (ERT) and hematopoietic stem cell transplantation, the cardiac and respiratory manifestations, hydrocephalus, and loss of auditory acuity are attenuated; however, there is no influence on the evolution of the musculoskeletal disease, therefore early diagnosis and surgical intervention are important for treatment. Although ERT has increased the survival of these patients, it is suspected that it may increase capsule-ligamentous laxity, thereby worsening the cervical instability. ${ }^{3}$

There are no well-defined criteria for surgical stabilization of the cervical spine, but clinical-radiological signs of myelopathy, significant instability, and neurophysiological changes provide good indications for the surgical approach. The craniocervical joint (CCJ) may be affected by instability, as well as by diffuse thickening of the dura mater and extradural soft tissues in the region, particularly the posterior longitudinal ligament, by deposits from the GAGs. ${ }^{4}$ This, in turn, can lead to symptoms of myelopathy affecting the neck, brainstem and cranial nerves. These are serious complications that are well-known in patients with MPS. ${ }^{5.6}$ In view of the unique characteristics of the JCC and the risk of damage to important neurological and vascular structures, along with the small number of cases and the technical difficulty of the surgical procedure, this work aims to evaluate the clinical-radiological results and complications. 


\section{METHODS}

A retrospective study on the forms of damage to the JCC, its diagnostic methods, surgical technique, results, and postoperative complications, in 10 patients with MPS associated with cervical stenosis and/or upper cervical instability. Information was collected from the medical records and the archive of images. Because this article is solely a review of the patient's medical records, it was not submitted to the ethics committee for approval.

In regard to indication, six of the patients exhibited signs clinical and radiological signs of stenosis of the craniocervical junction, whether in isolation or associated with other segments of the spinal column, while four showed signs of upper cervical instability.

The indications for surgery were based on clinical and radiological signs of myelopathy and/or neurophysiological signs of motor evoked potential or the presence of upper cervical instability. The decision to include the skull in the fusion was based on the presence of occipitocervical instability, GAG deposits extending to the clivus, and the impossibility of instrumentation of the lateral mass of $\mathrm{C} 1$.

The data related to the patients, the surgical technique, and complications are described in Table 1. We used the Nurick scale ${ }^{7}$ to functionally assess the deficit caused by myelopathy and the postoperative results. Two patients were excluded due to death from postoperative clinical complications.

Our study had a total of 10 patients; seven female and three

Table 1. List of patients with MPS

\begin{tabular}{|c|c|c|c|c|c|c|c|}
\hline & Sex & Age & $\begin{array}{l}\begin{array}{c}\text { Type } \\
\text { of } \\
\text { MPS }\end{array} \\
\end{array}$ & Diagnosis & Surgery & $\begin{array}{c}\text { Nurick } \\
\text { pre }\end{array}$ & $\begin{array}{c}\text { Nurick } \\
\text { post }\end{array}$ \\
\hline $\begin{array}{c}\text { Case } \\
1\end{array}$ & Female & $\begin{array}{c}2 \\
\text { years }\end{array}$ & MPS Vi & $\begin{array}{c}\text { Stenosis of the } \\
\text { CCJ }\end{array}$ & $\begin{array}{c}\text { Decompression } \\
\text { and occipito-C2 } \\
\text { fusion }\end{array}$ & II & 0 \\
\hline $\begin{array}{c}\text { Case } \\
2\end{array}$ & Female & $\begin{array}{c}6 \\
\text { years }\end{array}$ & MPS VI & $\begin{array}{c}\text { Instability due to } \\
\text { Os + GAG retro } \\
\text { dens }\end{array}$ & $\begin{array}{l}\text { C1-C2 fusion } \\
\text { harms }\end{array}$ & I & 0 \\
\hline $\begin{array}{c}\text { Case } \\
3\end{array}$ & Male & $\begin{array}{c}8 \\
\text { years }\end{array}$ & MPS VI & Stenosis CCJ & $\begin{array}{l}\text { C1-C2 fusion } \\
\text { harms }\end{array}$ & II & 0 \\
\hline $\begin{array}{c}\text { Case } \\
4\end{array}$ & Female & $\begin{array}{c}8 \\
\text { years }\end{array}$ & MPS VI & Stenosis CCJ & $\begin{array}{c}\text { Decompression } \\
\text { and C1-C2 fusion } \\
\text { harms }\end{array}$ & I & 0 \\
\hline $\begin{array}{c}\text { Case } \\
5\end{array}$ & Female & $\begin{array}{c}6 \\
\text { years }\end{array}$ & MPS VI & $\begin{array}{l}\text { Congen instab } \\
\text { due to the dens }\end{array}$ & $\begin{array}{l}\text { Instrumentation } \\
\text { C1-C2 crossed }\end{array}$ & 0 & 0 \\
\hline $\begin{array}{c}\text { Case } \\
6\end{array}$ & Male & $\begin{array}{c}8 \\
\text { years }\end{array}$ & MPS I & $\begin{array}{l}\text { Cervical } \\
\text { stenosis }\end{array}$ & $\begin{array}{l}\text { Occipito-C4 } \\
\text { fusion and de- } \\
\text { compression4 }\end{array}$ & V & II \\
\hline $\begin{array}{c}\text { Case } \\
7\end{array}$ & Male & $\begin{array}{c}9 \\
\text { years }\end{array}$ & MPS VI & $\begin{array}{c}\text { Cervical stenosis } \\
\text { with myeloma- } \\
\text { lacia }\end{array}$ & $\begin{array}{c}\text { Decompression } \\
\text { and occipito-C5 } \\
\text { fusion }\end{array}$ & V & V \\
\hline $\begin{array}{c}\text { Case } \\
8\end{array}$ & Female & $\begin{array}{c}11 \\
\text { years }\end{array}$ & MPS IV & \begin{tabular}{|c|} 
C1-C2 instab. \\
due to the dens \\
+ thoracolumbar \\
kyphosis with \\
mielopt \\
\end{tabular} & $\begin{array}{c}\text { C1-C2 fusion } \\
\text { (Harms and } \\
\text { Wright) }\end{array}$ & IV & III \\
\hline $\begin{array}{c}\text { Case } \\
9\end{array}$ & Female & $\begin{array}{c}18 \\
\text { years }\end{array}$ & MPS IV & \begin{tabular}{|c|} 
Double dural \\
compression of \\
the clivus as far \\
as C3) and thora- \\
cic kyphosis \\
\end{tabular} & $\begin{array}{c}\text { Decompression } \\
\text { and occipito-C6 } \\
\text { fusion }\end{array}$ & V & NALP \\
\hline $\begin{array}{c}\text { Case } \\
10\end{array}$ & Female & $\begin{array}{c}12 \\
\text { years }\end{array}$ & MPS IV & $\begin{array}{c}\text { Dens of the axis } \\
+ \text { instability C1- } \\
\text { C2 }+ \\
\text { myelopathy }\end{array}$ & $\begin{array}{c}\text { Occipito-C3 } \\
\text { fusion + decom- } \\
\text { pression }\end{array}$ & I & NALP \\
\hline
\end{tabular}

${ }^{\star}$ NALP - Not evaluated in the long term male. The mean age of the patients at the time of surgery was 8.8 years. Seven patients had MPS VI, two patients had MPS VAT, and one patient had MPS type I. Six patients presented some type of stenosis of the cervical spinal cord canal, and four had instability caused by the dens of the axis. Fifty percent of the patients underwent occipitocervical fusion (Figure 1) and 50\% underwent fusion (C1-C2. (Figure 2).

The patients remained in postoperative follow-up for at least two years, except for two, who died following surgery.

To evaluate the results of the surgery by the Nurick scale, we used the chi-squared test.

\section{RESULTS}

In our study, of the eight patients with long-term follow-up, seven presented preoperative neurological deficit, and of these, seven patients progressed to improvement of motor function, with improvement of at least one grade on the Nurick scale, and one patient remained the same in terms of neurological function. Two patients presented spinal cord compression due to thoracolumbar kyphosis associated with impairment of the CCJ, which could explain the incomplete motor recovery of the lower limbs on one of these patients. The two patients who underwent surgery, although asymptomatic, showed changes in myelopathy, which was confirmed by a neurophysiological exam. These same patients, after instrumentation and decompression,

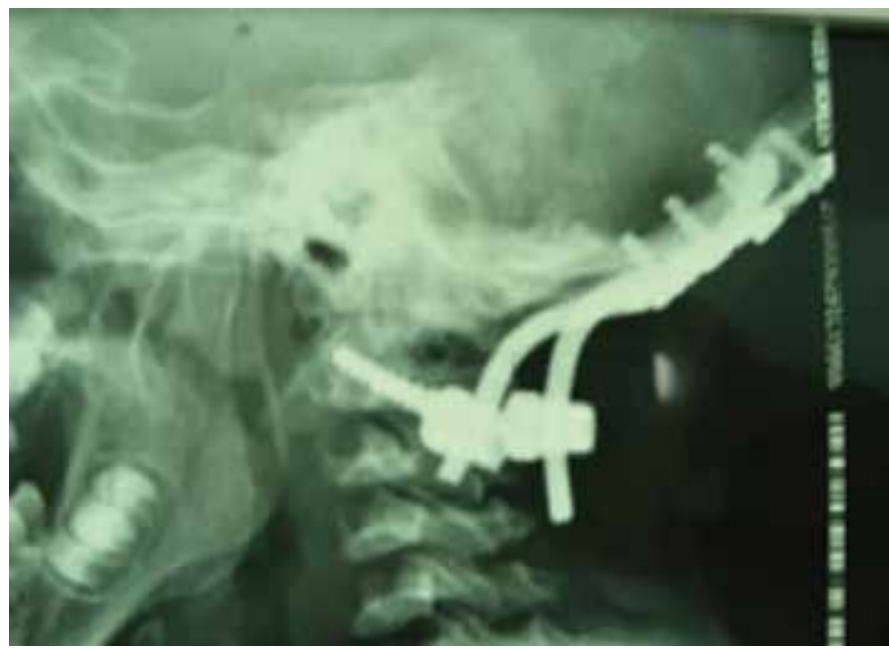

Figure 1. Lateral postoperative radiography, showing occipitocervical instrumentation with occipital plate and pedicle screws in C2.
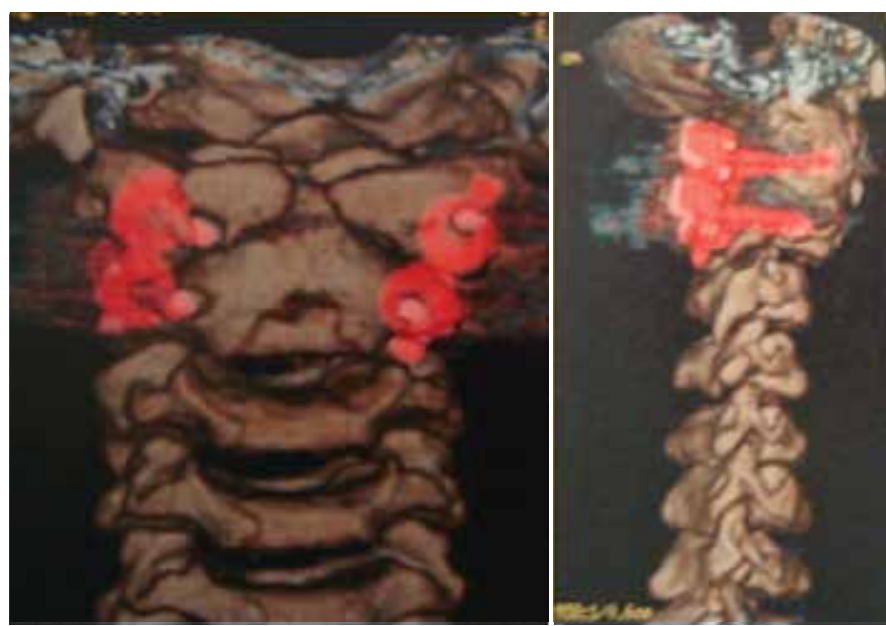

Figure 2. Three-dimensional reconstruction of postoperative craniocervical CT showing instrumentation with lateral mass screws in $\mathrm{C} 1$ and pedicle screws in $\mathrm{C} 2$. 
presented an improvement in corticospinal responses, staying at Nurick grade 0.

In terms of statistical significance, the study achieved $p \leq 0.05$ when we evaluated the Nurick score numerically for modification of the neurological status of all the patients, considering the pre- and postoperative clinical evaluations.

The sample is too small to evaluate this correlation, but of the six patients aged $\leq 8$ years, $5(83.4 \%)$ showed an improvement in Nurick score. On the other hand, of the two patients aged over eight years, only one (50\%) showed an improvement in Nurick score.

Although without statistical significance, $(p=0.35)$, patients with MPS type IV were four times more likely to require decompression $(\mathrm{OR}=4.0 ; \mathrm{Cl} 0.21-75.66)$ compared to the two levels above.

Two patients were excluded from the postoperative neurological and bone consolidation evaluation due to death during hospitalization, but due to the relevant sequelae, their details deserve mention. Case 9 had MPS VI, was 18 years of age, with advanced phenotype, valvar cardiopathy and double spinal cord compression at the craniocervical and thoracic level, with complete paralysis of the lower limbs. Treatment of the upper cervical compression was opted for, through decompression and occipitocervical fusion, without intraoperative intercurrences. The patient was extubated immediately after surgery, and on the third day after surgery, still under monitoring in a closed unit, developed acute abdomen, sepsis, and acute respiratory impairment. Submitted to explorative laparotomy, during which a perforated duodenal ulcer was evidenced, evolving to death five days later. Case 10 had MPS type VAl, aged 12 years, with neurophysiological signs of upper cervical compression. Submitted to upper craniocervical fusion with intraoperative motor evoked potential, not showing any detectable signal in the lower limbs. The patient woke up from the anesthesia with preserved neurological function in the upper limbs and remote paralysis of the lower limbs, with neurological level in T3 distant from the site of surgery. Evolved with pneumonia, respiratory impairment, and death, 15 days later.

The evaluation of bone consolidation through computed tomography (CT), performed six months after surgery, showed fusion in $100 \%$ of cases, confirmed by the presence of a bone bridge. There was no failure or migration of the instrumentation material in any of the cases.

In relation to intraoperative complications, there were two errors of positioning of the lateral mass screw of $\mathrm{C} 1$; one symptomatic and the other related to persistent migraine, which was attributed to radicular compression of $\mathrm{C} 2$. The first patient was kept in a cervical collar until complete radiological consolidation, confirmed by computed tomography. In the second patient, repositioning was performed with screws in a second surgical procedure, with complete remission of the symptoms.

One patient developed an acute infection at the surgical site, which was resolved with mechanical-surgical lavage and intravenous administration of antimicrobials.

\section{DISCUSSION}

Stenosis and occipitocervical instability are the most common manifestations of the cervical spine, and are present mainly in type IV (Morquio Syndrome), but also in type VI (Maroteaux-Lamy Syndrome) and in type I (Hurler Syndrome). There is no report of these symptoms in type III (Sanfilippo Syndrome). ${ }^{5}$ In our sample, there are seven patients with MPS type VI, one patient with MPS type I, and two patients with MPS type IV, contradicting the statistics present in the literature. ${ }^{8,9}$

Stenosis of the craniocervical junction is common in MPS, ${ }^{5}$ causing myelopathy and tetraparesis, with spinal cord compression being the most common cause of premature death in patients with MPS IV. ${ }^{6}$ This stenosis is caused by a build-up of GAGs posteriorly to the dens of the axis, associated with dural thickening and hypoplasia of the atlas arch, ultimately resulting in spinal cord compression. 4,10 This is further aggravated by atlantoaxial instability in patients with
Morquio syndrome, and by the presence of the dens of the axis. The manifestations of spinal cord compression can be diverse, depending on which portion of the spine is affected. Compression of the posterior region can result in changes in proprioception and vibratory sensitivity, while compression of the anterior region can cause decreased strength, hyperreflexia, and ataxia; when the vertebral artery is affected, the patient may present episodes of syncope and seizures; in most cases though, the patient will display signs and symptoms compatible with more than one compression site. ${ }^{11}$

In this study, the patients presented clinical and radiological signals of myelopathy secondary to stenosis of the craniocervical junction or instability. Of the ten patients, six had stenosis of the vertebral canal, and four patients had upper cervical instability. The stenosis was mainly due to an intracanal build-up of GAG, but in one case, it was due to dural thickening at the level of the clivus. The instability was identified mainly by the presence of the dens of the axis. Two patients presented concomitant deformity of the thoracic spine, associated with the stenosis.

The evaluation of stenosis of the craniocervical junction should begin with a complete neurological examination of the patient. The imaging study should start by requesting the radiographies in AP, profile (in neutral, in flexion and in extension) for investigation of instability, and transoral of the cervical spine. However, visualization of the CCJ is difficult with radiographs alone, and it is necessary to use computed tomography (CT), in order to better understand and dimension the bone anatomy of the region. Magnetic resonance (MRI) should be also requested, to evaluate the degree of stenosis of the canal and myelopathy, as it is now known that a sagittal diameter reduced to below $13 \mathrm{~mm}$ in adults is generally associated with changes in the neurological examination. ${ }^{3}$ All the patients of the study underwent the abovementioned tests. The natural history of spinal cord compression includes local ischemia, edema, and subsequent death of neural cells, ultimately causing myelomalacia. To assist in the evaluation of patients, we can also use motor evoked and somatosensitive potentials, which add a functional dimension of the spinal cord lesion. Some of our patients did not present clinical changes, but changes in motor evoked potential were observed in this preoperative evaluation.

At present, the clinical treatment of MPS begins as soon as the disease is diagnosed, with enzyme replacement therapy and/or hematopoietic stem cell transplant, depending on the type of MPS in question, increasing survival, and consequently, the possible need for spinal surgery. Although it attenuates the cardiac and respiratory manifestations, clinical treatment does not alter the evaluation of the musculoskeletal disease, ${ }^{5}$ as the leukocyte-derived enzymes have poor penetration in the bone tissue ${ }^{8}$ and instability can increase due to joint hyperlaxity, as occurred in one of our cases, and as reported by Daffne et al. ${ }^{8}$ Selecting which of these patients should undergo surgery is a challenge. There are still no well-defined criteria to indicate the surgical approach, but signs and symptoms of myelopathy, significant instability and changes in spinal cord observed in magnetic resonance all provide good indications. ${ }^{12-15}$

The choice of surgical technique should be made on a case-by-case basis. Given that spinal cord lesions are considered irreversible, and due to the risk of mortality due to cervical disease if the due treatment is not given, decompression - alone or associated with fusion - is performed prophylactically in patients at four years of age. However, some patients do not develop significant spinal cord injury over time, therefore individualized study of cases is of primary importance for the choice of treatment. . $^{3,16,17}$ As cited above, MPS leads, for various reasons, to spinal cord stenosis. The association of instability of the CCJ with this fact makes the situation very dangerous, and decompression and occipitocervical fusion by the posterior approach are necessary. ${ }^{17}$ When there is stenosis of more than one level of the spinal column, as mainly occurs in Hurler and Maroteaux-Lamy syndromes, decompression of multiple levels, laminoplasty, with or without fusion, is indicated. 3,14,17 $^{3}$

The techniques for posterior cervical fusion have undergone significant changes in recent years, which have improved the rigidity of the fixation system and brought considerable gains in rates of 
bone consolidation, ${ }^{18}$ which presented around $30 \%$ pseudarthrosis, when techniques with a halo and wires were used for the fixation.

The complex anatomy of CCJ, its biomechanical peculiarities, the presence of important structures in the surgical access, ${ }^{19}$ the existence of bone dysplasia in MPS, and the skeletal immaturity of the patient, with lateral masses and hypoplastic pedicles, as well as their reduced size, makes the surgical technique challenging. Thus, CT and MRI images must be carefully analyzed before executing the procedure, seeking to detail the course of the vertebral artery, the dimension of the lateral masses, and the direction and size of the pedicles to be instrumented. We carried out this careful planning in our patients, observing dysplastic changes in the vertebrae that needed to be included in the area of fusion.

Even with an adequate instrumentation technique, more modern materials, and careful studies in our patients, there were two cases of incorrect instrumentation in the lateral mass of $\mathrm{C} 1$, which we attributed to the difficulty of fluoroscopic control due to the bone hypoplasia. There was also one case of postoperative remote spinal cord infarction in our study. The patient had neurological function grade I on the Nurick scale, and after positioning on the procedure table, a worsening in motor evoked potential of the lower limbs was observed. On awakening, the patient had normal strength in the upper limbs, but paralysis in the lower limbs, remote, with neurological level in T3. We believe in the hypothesis of remote spinal cord infarction which, by definition, occurs when the neurological deficit emerges in a different site from the one addressed in the surgical procedure, which may occur due to the positioning in ven- tral decubitus to perform the procedure. ${ }^{20}$ Patients with deformity of the thoracic wall are at risk of remote spinal cord infarction. The causes are: regional hypoperfusion due to preexisting deformity in the vertebral spine; reduced cardiac debit, due to compression in the thoracic wall, previously deformed and reduced and/or large vessels; induced arterial hypotension, in the attempt to decrease blood loss. ${ }^{20}$ The association of navigation methods increases the precision of instrumentation, ${ }^{21-23}$ which would be of great value in these cases. The significant advance in techniques and materials used nowadays provides fusion rates close to $100 \%,{ }^{18}$ which were also achieved in all the patients of this study, with long-term postoperative follow-up. Based on the natural history of the disease, with permanent damage to the spinal cord due to stenosis and untreated instability, we observed that the earlier the treatment, the better the postoperative results, although the greater technical difficulty of the approach in younger patients is well-known.

\section{CONCLUSION}

The diagnosis and early intervention in cases of stenosis and/or cervical instability of patients with mucopolysaccharidosis provide patients with good recovery of neurological function, despite the great technical difficulty and the risk of complications.

All authors declare no potential conflict of interest concerning this article.

AUTHOR CONTRIBUTIONS: Each author made an individual and significant contribution to the development of the article. LECTS was the supervisor. LECTS and AGCB were the main surgeons and were also responsible for the bibliographic review and final revision of the article. LRC and CJC conducted the bibliographic review, collection of images and data from the patients, and elaboration of the text. RHT and RTS helped in the data collection, organization of the results, and correction of the text.

\section{REFERENCES}

1. Neufeld EF, Muenzer J. The mucopolysaccharidosis. In: Scriver CR, Beaudet AL, Sly WS, Valle D, Childs B, Kinzler KW, et al. editors. The metabolic and molecular basis of inherited disease. 8th ed. New York, NY: Mc Graw-Hill; 2001. p. 3421.

2. Clarke LA. The mucopolysaccharidoses: a success of molecular medicine. Expert Rev Mol Med. 2008:10:e1.

3. Horovitz DD, Magalhães TS, Pena e Costa A, Carelli LE, Souza e Silva D, de Linhares e Riello AP, et al. Spinal cord compression in young children with type VI mucopolysaccharidosis. Mol Genet Metab. 2011;104(3):295-300

4. Kircher S, Bajbouj M, Beck M. Mucopolysaccharidoses: a guide for physicians and parents. Bremen, Germany: Uni-Med Verlag AG; 2007.

5. White KK, Sousa T. Mucopolysaccharide disorders in orthopaedic surgery. J Am Acad Orthop Surg. 2013:21(1):12-22.

6. Thomas SL, Childress MH, Quinton B. Hypoplasia of the odontoid with atlanto-axial subluxation in Hurler's syndrome. Pediatr Radiol. 1985;15(5):353-4

7. Nurick S. The pathogenesis of the spinal cord disorder associated with cervical spondylosis. Brain. 1972;95(1):87-100.

8. McKay SD, Al-Omari A, Tomlinson LA, Dormans JP. Review of cervical spine anomalies in genetic syndromes. Spine (Phila Pa 1976). 2012;37(5):E269-77.

9. White KK, Sucatto D. Spinal deformity in skeletal dysplasia. Curr Opin Orthop 2006;17:499-510.

10. Vellodi A, Young EP, Cooper A, Wraith JE, Winchester B, Meaney C, et al. Bone marrow transplantation for mucopolysaccharidosis type I: experience of two British centres. Arch Dis Child. 1997;76(2):92-9.

11. Wills BP, Dormans JP. Nontraumatic upper cervical spine instability in children. J Am Acad Orthop Surg. 2006;14(4):233-45

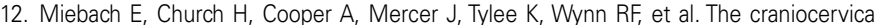
junction following successful haematopoietic stem cell transplantation for mucopolysaccharidosis type I H (Hurler syndrome). J Inherit Metab Dis. 2011;34(3):755-61.
13. Tandon V, Williamson JB, Cowie RA, Wraith JE. Spinal problems in mucopolysaccharidosis I (Hurler syndrome). J Bone Joint Surg Br. 1996;78(6):938-44.

14. Mut M, Cila A, Varli K, Akalan N. Multilevel myelopathy in Maroteaux-Lamy syndrome and review of the literature. Clin Neurol Neurosurg. 2005;107(3):230-5.

15. Solanki GA, Alden TD, Burton BK, Giugliani R, Horovitz DD, Jones SA, et al. A multinational, multidisciplinary consensus for the diagnosis and management of spinal cord compression among patients with mucopolysaccharidosis VI. Mol Genet Metab. 2012:107(1-2):15-24.

16. Stevens JM, Kendall BE, Crockard HA, Ransford A. The odontoid process in Morquio-Brailsford's disease. The effects of occipitocervical fusion. J Bone Joint Surg Br. 1991;73(5):851-8.

17. White KK, Steinman S, Mubarak SJ. Cervical stenosis and spastic quadriparesis in Morquio disease (MPS IV). A case report with twenty-six-year follow-up. J Bone Joint Surg Am. 2009:91(2):438-42.

18. Bransford RJ, Lee MJ, Reis A. Posterior fixation of the upper cervical spine: contemporary techniques. J Am Acad Orthop Surg. 2011:19(2):63-71.

19. Jackson RS, Banit DM, Rhyne AL 3rd, Darden BV 2nd. Upper cervical spine injuries. J Am Acad Orthop Surg. 2002;10(4):271-80.

20. Tong $\mathrm{CK}$, Chen JC, Cochrane DD. Spinal cord infarction remote from maximal compression in a patient with Morquio syndrome. J Neurosurg Pediatr. 2012;9(6):608-12.

21. Assaker R, Reyns N, Vinchon M, Demondion X, Louis E. Transpedicular screw placement: image-guided versus lateral-view fluoroscopy: in vitro simulation. Spine (Phila Pa 1976). 2001;26(19):2160-4

22. Holly LT, Foley KT. Three-dimensional fluoroscopy-guided percutaneous thoracolumbar pedicle screw placement. Technical note. J Neurosurg. 2003;99(Suppl 3):324-9.

23. Holly LT, Foley KT. Intraoperative spinal navigation. Spine (Phila Pa 1976). 2003;28(Suppl 15):S54-61. 